\title{
Ritme aktivitas penerbangan harian Tetragonula laeviceps (Smith) (Hymenoptera: Apidae) di Bogor
}

\author{
Daily flight activity rhythms of Tetragonula laeviceps (Smith) \\ (Hymenoptera: Apidae) in Bogor \\ Indah Putri Januar Yustia*, Aunu Rauf, Nina Maryana \\ Departemen Proteksi Tanaman, Fakultas Pertanian, Institut Pertanian Bogor \\ Jalan Kamper, Kampus IPB Dramaga, Bogor 16680
}

(diterima Agustus 2016, disetujui Maret 2017)

\begin{abstract}
ABSTRAK
Tetragonula laeviceps (Smith) adalah salah satu spesies lebah tak bersengat yang paling umum dijumpai di Indonesia. Namun demikian, tidak banyak publikasi tersedia tentang ritme aktivitas penerbangan T. laeviceps. Penelitian ini bertujuan mengkaji aktivitas penerbangan T. laeviceps dalam kaitannya dengan waktu harian dan berbagai unsur cuaca. Tiga koloni diamati setiap jam selama 5 menit dari pukul 06:00 hingga 18:00 WIB. Pengamatan meliputi banyaknya T. laeviceps yang keluar sarang, masuk sarang, membawa polen, membawa resin, dan membuang sampah. Hasil penelitian menunjukkan bahwa aktivitas penerbangan berbeda nyata $(\mathrm{P}<0,001)$ di antara jam-jam pengamatan. Secara umum, preferensi waktu (akrofase) aktivitas penerbangan terjadi pada pukul 11:00-12:00 WIB. Banyaknya T. laeviceps yang keluar dan masuk sarang berkorelasi positif (sedang) dengan suhu udara dan intensitas cahaya, tetapi berkorelasi negatif (sedang) dengan kelembapan relatif.
\end{abstract}

Kata kunci: aktivitas penerbangan, perilaku, teuweul

\begin{abstract}
Tetragonula laeviceps (Smith) is one of the most common species of stingless bees in Indonesia. However, only few publications available on the flight activity rhythms of the species. Research was conducted with the objectives to determine flight activity of $T$. laeviceps in relation to daily times and various weather elements. Three colonies of $T$. laeviceps were observed hourly for 5 minutes beginning at 06.00 a.m. until 06.00 p.m. Number of bees entering with pollen or resin, as well as exiting with waste were counted. Flight activity was significantly different $(\mathrm{P}<0.001)$ among times of day. The preferential times (acrophases) of flight activities occurred at afternoon (11 a.m. to 12 a.m.). Number of entrance and exit flights positively correlated (moderate) with temperature and light intensity, while negatively correlated (moderate) with relative humidity.
\end{abstract}

Key words: behavior, flight activity, stingless bees

\section{PENDAHULUAN}

Lebah tak bersengat (stingless bees) termasuk puak (tribe) Meliponini dari Famili Apidae (Hymenoptera). Di Indonesia lebah tak bersengat dikenal dengan beberapa nama, bergantung pada daerahnya, antara lain teuweul (Jawa Barat), klanceng (Jawa Tengah dan Jawa Timur), dan galo-galo (Sumatra Barat) (Erniwati 2013). Untuk selanjutnya, dalam tulisan ini lebah tak bersengat akan disebut teuweul. Di seluruh dunia terdapat 374 spesies teuweul yang tersebar di daerah

\footnotetext{
*Penulis korespondensi: Indah Putri Januar Yustia. Departemen Proteksi Tanaman, Fakultas Pertanian, Institut Pertanian Bogor

Jalan Kamper, Kampus IPB Dramaga, Bogor 16680, Tel: 085647574838, Email: indahputrijy@gmail.com
} 
tropika dan subtropika bagian selatan (Michener 2000). Di Indonesia diperkirakan terdapat 40-50 spesies teuweul (Schwarz 1937; Sakagami et al. 1990). Jenis yang paling umum dijumpai di seluruh pelosok Indonesia adalah Tetragonula laeviceps (Smith) (Sakagami et al. 1990; Erniwati 2013).

Seperti halnya lebah madu (puak Apini), teuweul juga melakukan penerbangan keluar sarang untuk mengumpulkan polen dan nektar dari tanaman. Polen berfungsi sebagai sumber protein (Souza et al. 1996; Jongjitvimol \& Wattanachaiyingcharoen 2006), sedangkan nektar merupakan sumber karbohidrat. Sebagian individu teuweul memberi makan larva dengan polen, sedangkan sumber nutrisi imago berasal dari polen dan nektar. Selain mengumpulkan polen dan nektar, teuweul juga mengumpulkan banyak resin tanaman untuk membangun, memperbaiki, dan melindungi sarang (Leonhardt 2010). Menurut Michener (1974), perkembangan koloni bergantung pada keberhasilan teuweul membawa sumber daya dari bunga-bunga terpilih ke dalam sarang. Sebagian dari teuweul di dalam koloni bertugas membuang sampah ke luar sarang, yaitu berupa eksuvia larva dan pupa, feses, sel yang tidak terpakai, dan bangkai lebah (Nunes-Silva et al. 2010).

Aktivitas penerbangan tersebut berlangsung siang hari dan dipengaruhi oleh faktor iklim (Hilario et al. 2001). Menurut Corbet et al. (1993) terdapat selang suhu ideal yang mendukung teuweul melakukan aktivitas di luar sarang. Pada teuweul yang berukuran kecil, seperti Nannotrigona testaceicornis (Lepeletier), aktivitas di luar sarang dimulai pada suhu $18{ }^{\circ} \mathrm{C}$ hingga $21{ }^{\circ} \mathrm{C}$ (Silva \& Gimenes 2014). Intensitas cahaya juga merupakan salah satu faktor cuaca yang memengaruhi aktivitas penerbangan (KleinertGiovannini 1982), khususnya yang terkait dengan mulainya aktivitas penerbangan (Lutz 1931). Heard \& Heindrikz (1993) yang meneliti Tetragonula carbonaria (Smith) mendapatkan adanya hubungan antara pola aktivitas penerbangan harian dengan suhu dan radiasi. Penerbangan $T$. carbonaria hanya terjadi pada suhu lebih besar dari $18{ }^{\circ} \mathrm{C}$ dan radiasi lebih besar dari $15 \mathrm{~W} \mathrm{~m}^{-2}$. Faktor cuaca lainnya, seperti kelembapan relatif untuk Plebeia pugnax Moure (Hilario et al. 2001) dan hujan untuk Melipona asilvai Moure
(Nascimento \& Nascimento 2012) dilaporkan memengaruhi aktivitas penerbangan teuweul tersebut. Waktu ketersediaan sumber daya bunga juga sangat memengaruhi aktivitas penerbangan di luar sarang. Oleh karena bunga tanaman umumnya mekar pada pagi hari maka banyak lebah yang mengunjungi bunga pada periode tersebut untuk mengumpulkan polen (Roubik 1989).

Pengetahuan tentang ritme penerbangan dan faktor cuaca yang memengaruhinya perlu dikuasai, terutama bila kita mempertimbangkan jasa ekosistem yang disediakan oleh teuweul. Di antara jasa tersebut adalah penyerbukan tanaman hutan (Roubik 1989) dan tanaman pertanian (Heard 1999). Penelitian ini bertujuan untuk mempelajari pola dan ritme aktivitas penerbangan teuweul T. laeviceps serta kaitannya dengan unsur cuaca, seperti suhu udara, kelembapan relatif, dan intensitas cahaya.

\section{BAHAN DAN METODE}

\section{Penyiapan koloni teuweul T. laeviceps}

Penelitian dilaksanakan selama bulan Oktober 2015. Tiga koloni teuweul T. laeviceps yang berukuran sama diambil dari Desa Cibeber 1, Leuwiliang, Kabupaten Bogor, Jawa Barat (dengan

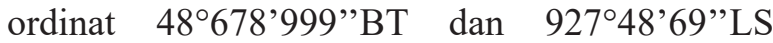
dengan ketinggian tempat $342 \mathrm{~m}$ dpl). Koloni kemudian dipindahkan dari kotak sarang lama ke kotak sarang baru $(\mathrm{p}=28 \mathrm{~cm}, 1=21 \mathrm{~cm}, \mathrm{t}=$ $11 \mathrm{~cm}$ ), yang ditempatkan di halaman Asrama Putri (A1) TPB, Kampus IPB Dramaga (dengan ordinat $06^{\circ} 33^{\prime} 20^{\prime \prime} \mathrm{LS}$ dan $106^{\circ} 43^{\prime} 48^{\prime \prime} \mathrm{BT}$ dengan ketinggian tempat $343 \mathrm{~m} \mathrm{dpl}$ ). Pada bagian depan kotak sarang diberi lubang dengan diameter $0,5 \mathrm{~cm}$ sebagai pintu masuk. Bagian atas kotak sarang ditutup dengan menggunakan plastik mika transparan $(\mathrm{p}=33 \mathrm{~cm}, 1=21 \mathrm{~cm})$, kemudian pada bagian atas plastik diberi kaca transparan $(p=35 \mathrm{~cm}$, $1=19 \mathrm{~cm}$ ), dan pada bagian atas kaca diberi papan triplek tipis $(p=26 \mathrm{~cm}, 1=19 \mathrm{~cm})$ sebagai pelindung koloni dari paparan cahaya.

\section{Pengamatan aktivitas penerbangan}

Untuk mempermudah penghitungan teuweul yang keluar-masuk sarang, terlebih dahulu disiapkan kerucut transparan, seperti yang dilakukan 
oleh Eltz (2001). Kerucut transparan terbuat dari bahan plastik mika $(\mathrm{p}=14 \mathrm{~cm}, 1=13 \mathrm{~cm})$ yang dilipat sehingga menyerupai bentuk corong. Pada bagian depan kerucut diberi lubang $(\mathrm{d}=0,5 \mathrm{~cm})$ tempat keluar-masuk teuweul, sedangkan bagian belakang kerucut mengarah ke bagian pintu masuk sarang, dan direkatkan pada kotak sarang menggunakan selotip. Teuweul yang keluarmasuk sarang akan melewati kerucut transparan ini sehingga dengan mudah dapat dihitung.

Pengamatan meliputi banyaknya teuweul yang keluar dan masuk sarang, membuang sampah, membawa polen, atau membawa resin. Teuweul yang keluar sambil membuang sampah dapat dikenali dari bagian mandibel yang tampak membawa bahan sampah. Teuweul yang masuk sambil membawa polen atau resin dapat dikenali dari korbikulanya. Jika teuweul membawa polen, pada korbikula tampak ada bahan berwarna kuning/jingga/putih tidak mengkilap, sedangkan jika membawa resin, pada korbikula tampak ada bahan berwarna putih/cokelat mengkilap. Dalam penelitian ini tidak dilakukan pengamatan langsung terhadap teuweul yang membawa nektar. Seluruh teuweul yang pada korbikula tidak terdapat polen atau resin diasumsikan membawa nektar di dalam perutnya. Sebaliknya, teuweul yang terbang keluar untuk membuang sampah umumnya segera kembali ke sarang, tanpa membawa nektar atau bahan lainnya. Dengan demikian, banyaknya teuweul yang membawa nektar dapat diduga dari banyaknya teuweul yang masuk sarang dikurangi yang membawa polen/resin dan yang membuang sampah (Nunes-Silva et al. 2010).

Pengamatan dilakukan setiap jam pada pukul 06:00-18:00 WIB dengan setiap pengamatan berlangsung selama 5 menit, seperti yang umum dilakukan untuk teuweul (e.g. Fidalgo \& Kleinert 2007). Selama penelitian berlangsung, dilakukan pengamatan sebanyak 6 kali sehingga keseluruhannya terdapat 216 pengamatan. Bila pada saat pengamatan terjadi hujan maka kegiatan pengamatan dihentikan. Selain itu, dilakukan pengukuran unsur-unsur cuaca, yaitu suhu udara dan kelembapan udara yang diukur menggunakan termohigrometer TFA Dostmann 30.5002, serta intensitas cahaya yang diukur dengan luxmeter Lutron LX-107.

\section{Analisis data}

Pengujian pendahuluan menunjukkan bahwa data aktivitas penerbangan tidak mengikuti sebaran normal (uji Kolmogorov-Smirnov, $\mathrm{P}$ $<0,05$ ) sehingga untuk pengujian selanjutnya digunakan analisis non-parametrik. Olah karena, dari 6 hari pengamatan terdapat 3 hari ada hujan dan 3 hari tanpa hujan maka untuk menguji perbedaan banyaknya teuweul yang melakukan penerbangan antara hari tanpa hujan dan hari ada hujan digunakan uji Mann-Whitney. Untuk membandingkan perbedaan banyaknya teuweul yang melakukan penerbangan antar jam-jam pengamatan digunakan uji Kruskal-Wallis. Untuk menguji adanya ritme penerbangan harian digunakan analisis statistik sirkular dan penentuan akrofase menggunakan uji Rayleigh (Zar 2010). Akrofase adalah waktu dengan peluang tertinggi terjadi aktivitas penerbangan. Panjang vektor rataan (r), yang memiliki nilai $0-1$, menunjukkan pencaran data di sekitar akrofase. Makin besar nilai $\mathrm{r}$ (mendekati 1), makin kecil pencaran data di sekitar akrofase (Zar 2010). Selain itu, dilakukan uji korelasi Spearman untuk memeriksa hubungan antara berbagai unsur cuaca (suhu udara, kelembapan relatif, dan intensitas cahaya) dengan aktivitas penerbangan teuweul dengan menggunakan taraf signifikan (P) $1 \%$ dan $5 \%$. Kategori korelasi didasarkan pada Fowler et al. (1998), yaitu sangat lemah $(0,00-0,19)$, lemah $(0,20-0,39)$, sedang $(0,40-0,69)$, kuat $(0,70-0,90)$, dan sangat kuat $(0,90-1,00)$. Seluruh analisis data tersebut menggunakan bantuan perangkat lunak SPSS 22 untuk Windows, sedangkan uji Rayleigh dengan bantuan perangkat lunak Oriana 4.02 untuk Windows yang dapat diunduh pada situs www.kovcomp.co.uk.

\section{HASIL}

\section{Ritme aktivitas penerbangan harian}

Hasil uji Mann-Whitney menunjukkan bahwa banyaknya teuweul yang keluar dan masuk sarang tidak berbeda nyata $(P>0,05)$ antara hari tanpa hujan dan hari ada hujan. Begitu pula banyaknya teuweul yang membawa polen, membawa resin, dan membuang sampah tidak berbeda nyata di antara kedua kelompok hari. Oleh karena itu, 
data dari kedua kelompok ini digabungkan pada analisis selanjutnya.

Hasil uji Kruskal Wallis terhadap data gabungan menunjukkan bahwa seluruh ritme aktivitas penerbangan $T$. laeviceps (keluar-masuk sarang, membawa polen, nektar, resin, membuang sampah) berbeda sangat nyata $(\mathrm{P}<0,001)$ di antara jam-jam pengamatan (Tabel 1). Aktivitas keluar dan masuk sarang sudah dimulai sejak pengamatan pukul 06:00 WIB, dengan rataan 5,94 individu yang keluar sarang dan 3,33 individu yang masuk sarang. Puncak aktivitas keluar sarang terjadi pada sekitar pukul 11:00 WIB (63,89 individu), sedangkan puncak aktivitas masuk sarang terjadi pada pukul 12:00 WIB (59,11 individu)(Gambar 1).

Aktivitas teuweul membawa polen dan nektar dimulai sejak pengamatan terpagi (pukul 06:00 WIB), dan berlangsung seharian hingga pengamatan yang terakhir (Gambar 2). Begitu pula aktivitas teuweul membawa resin berlangsung sejak pengamatan terpagi hingga yang paling sore. Banyaknya individu teuweul yang membawa nektar tertinggi terjadi pada pukul 11:00 hingga pukul 13:00 WIB, sedangkan yang membawa polen atau resin cenderung berfluktuasi. Aktivitas membuang sampah teramati mulai pukul 07:00 WIB dengan puncaknya (3 individu) terjadi pada pukul 09:00 WIB. Sampah yang dibuang berupa bangkai larva/imago, sisa makanan, dan sisa bahan yang digunakan untuk membuat sarang.

Hasil uji Rayleigh menunjukkan adanya preferensi waktu (akrofase) untuk seluruh aktivitas penerbangan harian, dengan panjang vektor rataan (r) berkisar 0,648-0,683 (P<0,001) (Tabel 2). Akrofase aktivitas keluar sarang terjadi pukul 11:10 WIB, lebih awal dibandingkan dengan aktivitas masuk sarang (pukul 11:33 WIB). Akrofase aktivitas membawa nektar (pukul 11:18 WIB), membawa polen (pukul 11:29 WIB), membawa resin (pukul 11:30 WIB), dan membuang sampah (pukul 11:28 WIB) terjadi hampir bersamaan, dengan selisih waktu antara 1-12 menit.

Tabel 1. Hasil uji Kruskal-Wallis perbedaan aktivitas penerbangan Tetragonula laeviceps di antara jam-jam pengamatan

\begin{tabular}{lcc}
\hline Aktivitas penerbangan & $\chi 2$ & $\mathrm{P}$ \\
\hline Keluar sarang & 104,655 & $<0,001$ \\
Masuk sarang & 100,448 & $<0,001$ \\
Membawa polen & 34,163 & $<0,001$ \\
Membawa resin & 30,943 & $<0,001$ \\
Membawa nektar & 108,196 & $<0,001$ \\
Membuang sampah & 49,069 & $<0,001$ \\
\hline
\end{tabular}

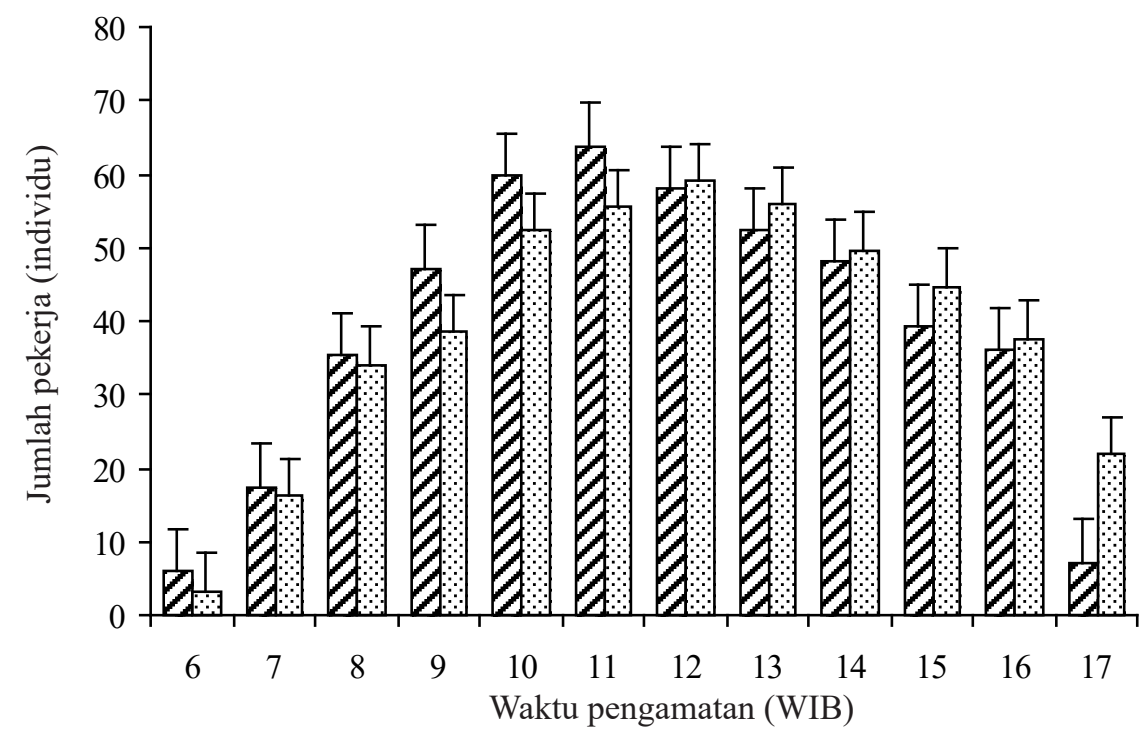

Gambar 1. Rataan dan galat baku banyaknya Tetragonula laeviceps yang melakukan aktivitas penerbangan.

$\mathbf{Q}$ : keluar sarang; $\mathbf{Q}$ : masuk sarang. 




Gambar 2. Rataan dan galat baku teuweul Tetragonula laeviceps yang $\mathbb{Z}$ : membawa polen; $\square$ : membawa resin, $\square$ : membawa nektar, dan $\boldsymbol{\square}$ : membuang sampah.

Tabel 2. Akrofase berbagai aktivitas penerbangan harian Tetragonula laeviceps berdasarkan uji Rayleigh

\begin{tabular}{lcccccc}
\hline \multirow{2}{*}{ Rincian } & \multicolumn{7}{c}{ Aktivitas penerbangan } \\
\cline { 2 - 7 } & $\begin{array}{c}\text { Keluar } \\
\text { sarang }\end{array}$ & $\begin{array}{c}\text { Masuk } \\
\text { sarang }\end{array}$ & $\begin{array}{c}\text { Membawa } \\
\text { polen }\end{array}$ & $\begin{array}{c}\text { Membawa } \\
\text { resin }\end{array}$ & $\begin{array}{c}\text { Membawa } \\
\text { nektar }\end{array}$ & $\begin{array}{c}\text { Membuang } \\
\text { sampah }\end{array}$ \\
\hline Banyaknya penerbangan (individu) & 202 & 212 & 197 & 174 & 197 & 162 \\
Akrofase (jam:menit) & $11: 10$ & $11: 33$ & $11: 29$ & $11: 30$ & $11: 18$ & $11: 28$ \\
Panjang vektor rataan & 0,671 & 0,648 & 0,659 & 0,659 & 0,683 & 0,672 \\
P & $<0,001$ & $<0,001$ & $<0,001$ & $<0,001$ & $<0,001$ & $<0,001$ \\
\hline
\end{tabular}

\section{Hubungan antara aktivitas penerbangan harian dan faktor cuaca}

Hasil pengukuran unsur-unsur cuaca harian di sekitar sarang teuweul disajikan pada Gambar 3. Rataan suhu udara pada pukul 06:00 WIB tercatat $24,56{ }^{\circ} \mathrm{C}$, kemudian meningkat pada siang hari dengan puncaknya pada pukul 13:00 WIB (34,71 $\left.{ }^{\circ} \mathrm{C}\right)$, dan menurun lagi $\left(28,75^{\circ} \mathrm{C}\right)$ pada pukul 17:00 WIB. Tidak seperti suhu, perubahan intensitas cahaya harian sangat tajam, dengan puncaknya (43,39 klux) terjadi pada pukul 11:00 WIB. Pola yang berbeda ditunjukkan oleh kelembapan udara, yaitu tinggi (74,11\%) pada pukul 07:00 WIB, menurun $(37,33 \%)$ pada pukul 14:00 WIB, dan kemudian meningkat kembali $(56,39 \%)$ pada pukul 17:00 WIB.

Hasil analisis korelasi antara unsur-unsur cuaca dan aktivitas penerbangan disajikan pada Tabel 3. Suhu udara dan intensitas cahaya berkorelasi positif dengan seluruh aktivitas penerbangan. Koefisien korelasi antara aktivitas keluar sarang dan suhu udara $\left(\mathrm{r}_{\mathrm{s}}=0,502 ; \mathrm{P}<0,001\right)$ dan intensitas cahaya $\left(\mathrm{r}_{\mathrm{s}}=0,539 ; \mathrm{P}<0,001\right)$ termasuk kategori sedang. Begitu pula korelasi antara aktivitas masuk sarang dan suhu udara $\left(\mathrm{r}_{\mathrm{s}}=0,559 ; \mathrm{P}<0,001\right)$ dan intensitas cahaya $\left(r_{\mathrm{s}}=0,424 ; \mathrm{P}<0,001\right)$ tergolong sedang. Sementara itu, korelasi antara suhu udara dan aktivitas membawa polen, membawa resin, serta membuang sampah tergolong sangat lemah $\left(r_{\mathrm{s}}<0,20\right)$. Begitu pula korelasi antara intensitas cahaya dan aktivitas membawa polen $\left(\mathrm{r}_{\mathrm{s}}=0,163\right)$, membawa resin $\left(r_{s}=0,279\right)$, dan membuang sampah $\left(r_{s}=0,244\right)$ tergolong sangat lemah hingga lemah. Berbeda dengan suhu udara dan intensitas cahaya, kelembapan udara berkorelasi negatif dengan seluruh aktivitas penerbangan. Walaupun demikian, korelasi kelembapan dengan aktivitas keluar sarang $\left(\mathrm{r}_{\mathrm{s}}=-0,499 ; \mathrm{P}<0,001\right)$ dan masuk sarang $\left(r_{\mathrm{s}}=-0,550 ; \mathrm{P}<0,001\right)$ tergolong sedang. Korelasi antara kelembapan udara dan aktivitas membawa polen $\left(\mathrm{r}_{\mathrm{s}}=-0,130\right)$, membawa resin $\left(\mathrm{r}_{\mathrm{s}}\right.$ $=-0,102)$, dan membuang sampah $\left(\mathrm{r}_{\mathrm{s}}=-0,057\right)$ termasuk kategori sangat lemah. 


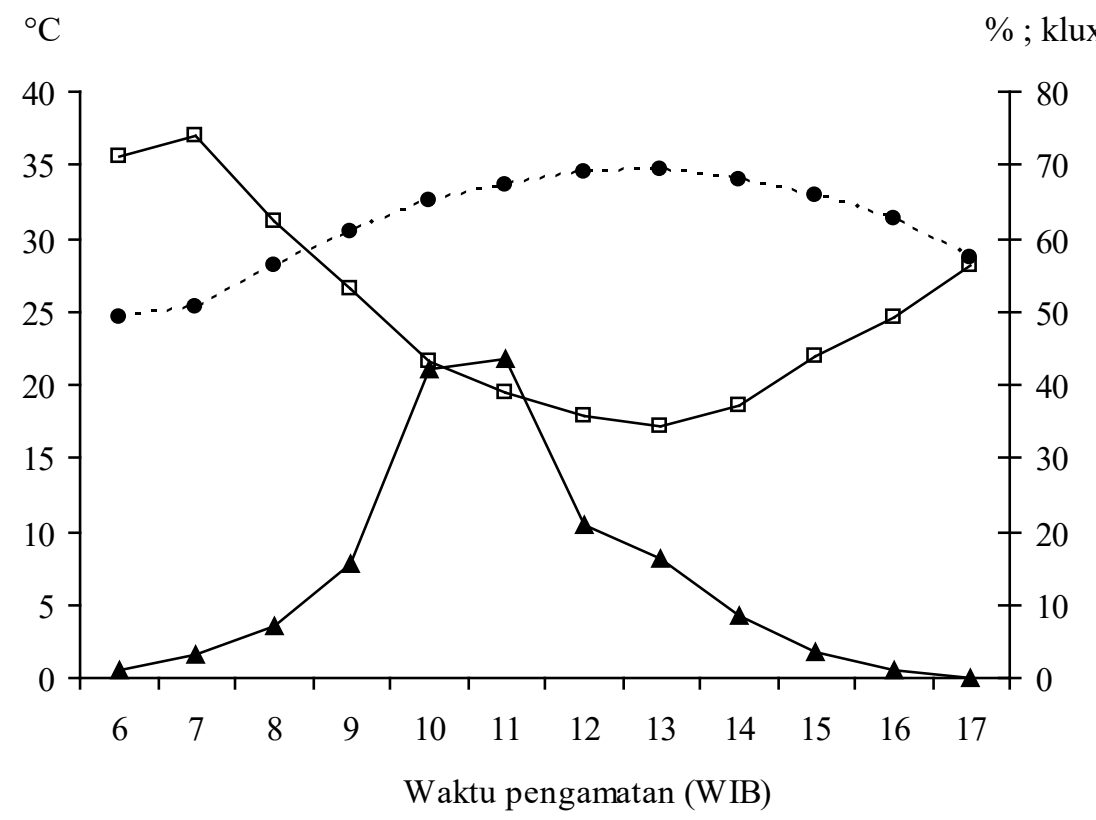

Gambar 3. Rataan suhu udara, kelembapan relatif, dan intensitas cahaya di lokasi penelitian. --•--.- : suhu udara; ——: kelembapan udara; dan ——: intensitas cahaya.

Tabel 3. Korelasi Spearman $\left(\mathrm{r}_{\mathrm{s}}\right)$ antara unsur cuaca dan aktivitas penerbangan Tetragonula laeviceps

\begin{tabular}{lccc}
\hline \multirow{2}{*}{ Aktivitas penerbangan } & \multicolumn{3}{c}{ Unsur cuaca } \\
\cline { 2 - 4 } & Suhu udara & Kelembapan udara & Intensitas cahaya \\
\hline Keluar sarang & $0,502^{* *}$ & $-0,499^{* *}$ & $0,539^{* *}$ \\
Masuk sarang & $0,559^{* *}$ & $-0,550^{* *}$ & $0,424^{* *}$ \\
Membawa polen & $0,182^{* *}$ & $-0,130$ & $0,163^{*}$ \\
Membawa resin & 0,103 & $-0,102$ & $0,279^{* *}$ \\
Membawa nektar & $0,612^{* *}$ & $-0,602^{* *}$ & $0,446^{* *}$ \\
Membuang sampah & 0,062 & $-0,057$ & $0,244^{* *}$ \\
\hline
\end{tabular}

** berbeda nyata pada taraf uji $1 \%$, * berbeda nyata pada taraf uji 5\%; tanpa tanda bintang: tidak berbeda nyata.

\section{PEMBAHASAN}

Dalam penelitian ini diperoleh bahwa banyaknya penerbangan teuweul tidak berbeda nyata antara hari tanpa hujan dan hari ada hujan. Hal ini bukan berarti bahwa hujan tidak berpengaruh terhadap aktivitas penerbangan teuweul, tetapi karena hujan terjadinya pada sore hari (sekitar pukul 17:00 WIB), pada saat aktivitas penerbangan sedikit. Diperkirakan pengaruhnya akan sangat nyata seandainya hujan terjadi siang hari, pada saat banyak berlangsung penerbangan. Pengamatan Figueiredo-Mecca et al. (2013) menunjukkan bahwa teuweul Scaptotrigona depilis (Moure) mengurangi aktivitasnya di luar sarang pada saat hujan. Hal yang sama dilaporkan pula pada Plebeia remota (Holmberg) (Hilario et al. 2001). Pengaruh hujan juga dapat ditelusuri dari studi yang membandingkan aktivitas penerbangan antara musim kemarau dan musim hujan. Pada teuweul M. asilvai di Brasil, aktivitas penerbangan menurun hampir $90 \%$ pada musim hujan dibandingkan pada musim kemarau (Nascimento \& Nascimento 2012). Diperkirakan pola yang sama terjadi pula pada $T$. laeviceps di Indonesia.

Hasil penelitian ini juga mengungkapkan adanya ritme penerbangan harian dari $T$. laeviceps. Penerbangan keluar sarang dimulai oleh beberapa individu pada pagi hari (pukul 06:00 WIB), kemudian meningkat pada siang hari, dan menurun lagi menjelang senja. Penerbangan masuk sarang 
juga memperlihatkan ritme yang sama. Ritme aktivitas penerbangan tersebut kemungkinan berhubungan dengan faktor intrinsik, seperti memori dan ambang respons individu terhadap stimulus serta faktor ekstrinsik, seperti cuaca dan kondisi koloni (Nascimento \& Nascimento 2012). Kedua faktor ini pada akhirnya akan menciptakan terbentuknya ritme aktivitas penerbangan. Teuweul T. laeviceps yang sehari-hari mencari nektar, polen, dan resin diperkirakan mampu mempelajari kondisi di luar sarang dan menghubungkan antara tempat dan waktu ketersediaan nektar atau polen sehingga penerbangan menjadi lebih efektif. Fenomena time-place learning ini telah dibuktikan secara eksperimental pada teuweul Trigona amalthea (Olivier) (Breed et al. 2002) dan Melipona fasciculata Smith (Hymenoptera: Apidae) (de Jesus et al. 2014).

Penerbangan yang terjadi pada jam-jam tertentu mengindikasikan adanya ritme biologi sebagai hasil dari bekerjanya faktor intrinsik yang berupa mekanisme jam biologi (biological clock), seperti dilaporkan banyak terjadi pada serangga (Koukkari \& Sothern 2006). Ritme biologi yang terkait dengan pola aktivitas penerbangan harian dilaporkan terjadi pada berbagai jenis teuweul, di antaranya $N$. testaceicornis (Silva \& Gimenes 2014), Melipona scutellaris Latreille dan Frieseomellita doederleini (Friese) (Gouw \& Gimenes 2013), dan Melipona rufiventris Lepeletier(Fidalgo \& Kleinert 2007). Ritme biologi ini berhubungan dengan siklus harian, seperti waktu terbit dan terbenamnya matahari. Bellusci \& Marques (2001) mendapatkan bahwa aktivitas penerbangan $S$. depilis keluar sarang mengikuti ritme sirkadian, yang kemungkinan dipengaruhi oleh faktor lingkungan dan ketersediaan sumber pakan. Dalam kaitan ini, ritme aktivitas harian $T$. laeviceps diduga berhubungan dengan pengaruh faktor cuaca atau waktu mekarnya bunga. Tumbuhan yang ada pada radius $50 \mathrm{~m}$ dari koloni adalah sangga langit (Tridax procumbens L.), patikan kebo (Euphorbia hirta L.), mahkota duri (Euphorbia milli Des Moul.), remek watu(Hedyotis auricularia L.), jembirit (Tabernaemontana orientalis R. Br.), dan tembelekan (Lantana camara L.). Selain jenis polen dari keenam spesies tumbuhan tersebut, pada korbikula pekerja ditemukan juga jenis polen dari spesies tumbuhan lain terutama dari Famili Rubiaceae (Yustia 2016). Ketersediaan pakan yang terbatas di lokasi sekitar sarang diduga menyebabkan $T$. laeviceps mencari sumber pakan di lokasi yang agak jauh dari sarang. Hal inilah yang mungkin menyebabkan akrofase penerbangan T. laeviceps terjadi menjelang tengah hari. Berbeda dengan aktifitas penerbangan lainnya, aktivitas membuang sampah tampaknya lebih dipengaruhi oleh faktor internal sarang (Nunes-Silva et al. 2010). Souza et al. (2006) melaporkan adanya korelasi positif antara jumlah polen dan nektar dengan sampah yang dihasilkan koloni M. asilvai (Hymenoptera: Apidae).

Di antara faktor cuaca yang memengaruhi aktivitas penerbangan adalah suhu udara. Beberapa spesies dari Meliponini tidak akan keluar sarang sebelum suhu udara mencapai $19^{\circ} \mathrm{C}$, sedangkan M. scutellaris keluar sarang pada suhu $24{ }^{\circ} \mathrm{C}$ dan $F$. doederleini pada suhu $27^{\circ} \mathrm{C}$ (Gouw $\&$ Gimenes 2013). Walaupun demikian, di Bogor (suhu $25^{\circ} \mathrm{C}$ pada pukul 06:00 WIB) dan Indonesia pada umumnya tampaknya suhu udara bukan merupakan faktor pembatas penerbangan teuweul. Di Indonesia, intensitas cahaya diperkirakan lebih berpengaruh pada aktivitas penerbangan teuweul. Secara umum, awal dan akhir dari aktivitas penerbangan teuweul terjadi menjelang terbit dan terbenamnya matahari. Pada penelitian ini intensitas cahaya minimum yang menginisiasi aktivitas penerbangan $T$. laeviceps, yaitu 0,041 klux. Bomfim et al. (2014) mendapatkan bahwa Scaptotrigona sp. nov. memulai aktivitas penerbangan pada intensitas cahaya 1,79 klux. Pengaruh intensitas cahaya siang hari terhadap penerbangan teuweul terlihat pada saat terjadi gerhana matahari. Aktivitas penerbangan teuweul T. laeviceps berkurang sekitar separuhnya pada jam-jam terjadinya gerhana matahari (Yustia et al. 2016). Berbeda dengan suhu dan intensitas cahaya yang berkorelasi positif dengan aktivitas penerbangan, kelembapan udara berkorelasi negatif. Hal ini tampaknya lebih disebabkan oleh menurunnya kelembapan udara pada siang hari, pada saat aktivitas penerbangan meningkat sebagai akibat dari meningkatnya suhu dan intensitas cahaya. Hilario et al. (2012) juga mendapatkan korelasi negatif antara kelembapan udara dan aktivitas penerbangan pada teuweul $P$. remota. 


\section{KESIMPULAN}

Teuweul T. laeviceps memperlihatkan ritme aktivitas penerbangan harian, dengan akrofase terjadi pada pukul 11:00-12:00 WIB. Aktivitas penerbangan berkorelasi positif dengan suhu udara dan intensitas cahaya, serta berkorelasi negatif dengan kelembapan relatif.

\section{UCAPAN TERIMA KASIH}

Penelitian ini merupakan bagian dari tesis penulis pertama pada Program Studi Entomologi Sekolah Pascasarjana-IPB, melalui beasiswa BPPDN-DIKTI.

\section{DAFTAR PUSTAKA}

Bellusci S, Marques MD. 2001 Circadian activity rhythm of the foragers of a eusocial bee (Scaptotrigona aff depilis, Hymenoptera, Apidae, Meliponinae) outside the nest. Biological Rhythm Research 32:117-124.

Bomfim I, Bezerra ADM, Nunes AC, Aragao FAS, Freitas BM. 2014. Adaptive and foraging behavior of two stingless bee species (Apidae: Meliponini) in greenhouse mini watermelon pollination. Sociobiology 61:502-509.

Breed MD, Stocker EM, Baumgartner LK, Vargas S. 2002. Time-place learning and the ecology of recruitment in a stingless bee, Trigona amalthea (Hymenoptera, Apidae). Apidologie 33:251258. doi: https://doi.org/10.1051/apido:2002018.

Corbet SA, Fussell M, Ake R, Fraser A, Gunson C, Savage A, Smith K. 1993. Temperature and pollination activity of social bees. Ecological Entomology 18:17-30. doi: https://doi. org/10.1111/j.1365-2311.1993.tb01075.x.

de Jesus TNCS, Venturieri GC, Contrera FAL. 2014. Time-place learning in the bee Melipona fasciculata (Apidae, Meliponini). Apidologie 45:257-265. doi: https://doi.org/10.1007/s13592013-0245-2.

Eltz T. 2001. Ecology of Stingless Bees (Apidae, Meliponini) in Lowland Dipterocarp Forests in Sabah, Malaysia, and an Evaluation of Logging Impact on Populations and Communities. $\mathrm{PhD}$ Thesis. Germany: Wuzburg University.

Erniwati. 2013. Kajian biologi lebah tak bersengat (Apidae: Trigona) di Indonesia. Fauna Indonesia 12:29-34.
Fidalgo AO, Kleinert AMP. 2007. Foraging behavior of Melipona rufiventris Lepeletier (Apinae: Meliponini) in Ubatuba, SP, Brazil. Brazilian Journal of Biology 67:137-144. doi: https://doi. org/10.1590/S1519-69842007000100018.

Figueiredo-Mecca G, Bego LR, Nascimento FS. 2013. Foraging behavior of Scaptotrigona depilis (Hymenoptera, Apidae, Meliponini) and its relationship with temporal and abiotic factors. Sociobiology 60:277-282. doi: https:// doi.org/10.13102/sociobiology.v60i3.267-282.

Fowler J, Cohen L, Jarvis P. 1998. Practical Statistics for Field Biology. Chichester: John Wiley \& Sons.

Gouw MS, Gimenes M. 2013. Differences of the daily fight rhythm in two neotropical stingless bees (Hymenoptera, Apidae). Sociobiology 60:183-189. doi: https://doi.org/10.13102/ sociobiology.v60i2.183-189.

Heard TA. 1999. The role of stingless bees in crop pollination. Annual Review of Entomology 44:183-206. doi: https://doi.org/10.1146/annurev. ento.44.1.183.

Heard TA, Hendrikz JK. 1993. Factors influencing flight activity of colonies of the stingless bee Trigona carbonaria (Hymenoptera: Apidae). Australian Journal of Zoology 41:343-353. doi: https://doi.org/10.1071/ZO9930343.

Hilario SD, Imperatriz-Fonseca VL, Kleinert A. 2001. Responses to climatic factors by foragers of Plebeia pugnax Moure (Apidae, Meliponinae). Revista Brasileira de Biologia 61:191-196. doi: https://doi.org/10.1590/S003471082001000200003.

Hilario SD, Ribeiro MF, Imperatriz-Fonseca VL. 2012. Can climate shape flight activity patterns of Plebeia remota (Hymenoptera: Apidae)? Iheringia SerieZoologia 102:269-276. doi:https:// doi.org/10.1590/S0073-47212012000300004.

Jongjitvimol T, Wattanachaiyingcharoen W. 2006. Pollen food sources of the stingless bees Trigona apicalis Smith 1857, Trigona collina Smith 1857, and Trigona fimbriata Smith 1857 (Apidae, Meliponinae) in Thailand. The Natural Hisyory Journal of Chulalongkorn University 6:75-82.

Kleinert-Giovannini A. 1982. The influence of climatic factors on flight activity of Plebeia emerina Friese (Hymenoptera, Apidae, Meliponinae) in winter. The Revista Brasileira de Entomologia 26:1-13.

Koukkari W, Sothern R. 2006. Introducing biological rhythms. St. Paul: Springer.

Leonhardt SD. 2010. Resin Collection and Use in Stingless Bees. PhD Thesis. Germany: Wuzburg University. 
Lutz FE. 1931. Light as a factor in controlling the start of daily activity of a wren and stingless bees. American Museum of Natural Hystory 468:1-4.

Michener CD. 1974. The Social Behaviour of the Bees: A Comparative Study. Cambridge: Harvard University Press.

Michener CD. 2000. The Bees of The World. Baltimore, Maryland: The Johns Hopkins University Press.

Nascimento DL, Nascimento FS. 2012. Extreme effects of season on the foraging activities and colony productivity of a stingless bee (Melipona asilvei Moure) in Northeast Brazil. Psyche 2012: 1-6. doi: https://doi.org/10.1155/2012/267361.

Nunes-Silva P, Hilario SD, Filho PSS, ImperatrizFonseca VL. 2010. Foraging activity in Plebeia remota, a stingless bee species, is influenced by the reproductive state of a colony. Psyche 2010:116. doi: https://doi.org/10.1155/2010/241204.

Roubik DW. 1989. Ecology and Natural History of Tropical Bees. Cambridge: Cambridge University Press. doi: https://doi.org/10.1017/ CBO9780511574641.

Sakagami SF, Inoue T, Salmah S. 1990. Stingless bees of Central Sumatra. In: Ohgushi R, Sakagami SF, Roubik DW (Eds). Natural History of Social bees in Equatorial Sumatra. pp.125-137. Japan: Hokaido University Press.

Schwarz HF. 1937. The Indo-Malayan species of Trigona. Bulletin of the American Museum of Natural History 76:83-141.
Silva WP, Gimenes M. 2014. Pattern of the daily flight activity of Nannotrigona testaceicornis (Lepeletier) (Hymenoptera: Apidae) in the Brazilian semiarid region. Sociobiology 61:547553. doi: https://doi.org/10.13102/sociobiology. v61i4.547-553.

Souza ACM, Moura CO, Nelson BW. 1996. Pollen collected by Trigona williana (Hymenoptera: Apidae) in Central Amazonia. Revista de Biologia Tropical 44:567-573.

Souza BA, Carvalho CAL, Alves RMO. 2006. Flight activity of Melipona asilvai Moure (Hymenoptera: Apidae). Brazilian Journal of Biology 66:731-737. doi: https://doi. org/10.1590/S1519-69842006000400017.

Yustia IPJ. 2016. Aktivitas Penerbangan Harian Teuweul Tetragonula laeviceps (Smith) (Hymenoptera) dalam Hubungannya dengan Status Koloni dan Faktor Cuaca. Tesis. Bogor: Institut Pertanian Bogor.

Yustia IPJ, Adriani E, Maharani JS, Saraswati A, Masyitah S, Fanani MZ, Wakhid, Rauf A. 2016. Pengaruh gerhana matahari terhadap aktivitas terbang teuweul Trigona laeviceps di Bogor. Tersedia di: http://ptn.ipb.ac.id/index. php/en/item/238-pengaruh-gerhana-matahariterhadap-aktivitas-terbang-teuweul-trigonalaeviceps-di-bogor. [diakses pada 2016]

Zar JH. 2010. Biostatistical Analysis $5^{\text {th }}$ ed. New Jersey: Prentice Hall, Inc. 